\title{
Hospital Cost of Staphylococcal Infection after Cardiothoracic or Orthopedic Operations in France: A Retrospective Database Analysis
}

\author{
Aurélie Schmidt, Stève Bénard, and Sonya Cyr ${ }^{2}$
}

\begin{abstract}
Background: Staphylococcal infections (SI) after cardiothoracic (CT) or orthopedic (OP) surgery are associated with extended length of stay (LOS), a considerable mortality rate, and high cost. No data on these consequences have been published in France. Therefore, a study was conducted to describe the epidemiologic, clinical, and economic outcomes of SI following these operations in France based on a hospital discharge database.

Methods: Patients who underwent the most common types of CT or OP operations in 2009 were identified and followed for one year. Staphylococcal infections occurring in the three following months were identified.

Results: In 2009, 21,543 patients underwent one of the selected CT procedures (62\% coronary artery bypass grafting; 38\% cardiac valve replacement) and 175,518 patients underwent one of the selected OP procedures (64\% hip arthroplasty; 36\% knee arthroplasty). Among the patients, $4.4 \%(\mathrm{n}=955)$ and $0.9 \%(\mathrm{n}=1,515)$ developed SI after CT and OP surgery, respectively. Staphylococcal infection led to approximately 1.0 and 1.4 additional hospitalizations per patient, 22.1 and 24.1 additional hospital days, and an excess cost of $€ 15,475$ and $€ 13,389$ after an CT or OP procedure, respectively. The in-hospital mortality rate was 2.6 times and 6 times greater in infected patients than in non-infected patients for CT and OP. Hospital cost reached $€ 505$ million for these two CT procedures and $€ 1.9$ billion for the two OP procedures, of which $€ 15$ million and $€ 20$ million were related directly to patients having developed SI.

Conclusions: Staphylococcal infections after common CT or OP operations were associated with greater mortality rates and hospital costs secondary to the additional procedures and greater LOS.
\end{abstract}

A LTHOUGH THE PREVALENCE of nosocomial infections (NI) has been reduced recently through measures carried out by health authorities, NI are still associated with higher medical costs, extended length of stay (LOS), high complication rates, and an overall increase in morbidity and mortality rates [1]. The mean global cost of NI has been estimated at around $€ 760$ million per year for European member countries of the Organization for Economic Cooperation and Development (OECD) [2]. However, few data are available at the national level.

In France, a surveillance network dedicated to NI conducted a national survey in 2012 and reported a prevalence of NI of 5.3\% among more than 300,000 hospitalized patients. Overall, $15.9 \%$ of NI were caused by Staphylococcus aureus (including 38.1\% methicillin-resistant S. aureus [MRSA] infections) [3]. Staphylococcus aureus is one of the leading causes of infection in the surgical ward, especially for patients who undergo cardiothoracic (CT) or orthopedic (OP) operations [3-8]. The economic burden of NI and staphylococcal infections (SI) among surgical patients is considerable, with a substantial impact on patient morbidity and death, as well as health care cost $[6,9,10]$.

Limited data have been published on the burden of these infections in France. Therefore, the objective of this study was to describe the epidemiology and the clinical and financial outcomes of SI after coronary artery bypass grafting $(\mathrm{CABG})$ or cardiac valve replacement $(\mathrm{CT})$ or hip or knee arthroplasty (OP) surgery in France in 2009 through an analysis of the French hospital discharge database (PMSI).

\footnotetext{
${ }^{1}$ St[è]ve Consultants, Oullins, France.

${ }^{2}$ GSK Vaccines, Rixensart, Belgium.
}

(C) Aurélie Schmidt, Stève Bénard, and Sonya Cyr 2015; Published by Mary Ann Liebert, Inc. This Open Access article is distributed under the terms of the Creative Commons Attribution Noncommercial License (http://creativecommons.org/licenses/by-nc/4.0/) which permits any noncommercial use, distribution, and reproduction in any medium, provided the original author(s) and the source are credited. 


\section{Patients and Methods}

\section{Database description}

Approval for the database analysis was obtained from the National Commission on Informatics and Liberty (CNIL). Retrospective analysis of patient-level data was conducted from the PMSI, an exhaustive dataset based on DiagnosisRelated Groups (DRG), which includes all patient admissions in French public and private hospitals and clinics, covering the entire French population. Each stay is associated with a principal diagnosis (PD), related diagnosis (RD), and associated diagnosis (AD), all of which are coded according to the International Classification of Diseases, version 10 (ICD-10). Surgical procedures are defined according to the French Common Classification of Medical Acts (CCMA). Multiple hospitalizations are linked to anonymized patient data using a unique and encrypted patient number to create the database.

\section{Study design}

The study population consisted of patients who underwent CT or OP surgery in 2009 and was identified on the basis of CCMA-defined procedures. The most common procedures related to OP (knee and hip arthroplasty) and CT surgery (CABG or valve replacement) were selected (Appendix 1). Any patient having undergone one or more of these operations between 1 January 2009 and 31 December 2009 was identified from the database. Patients with a hospital stay for any reason within $90 \mathrm{~d}$ before the selected CT or OP operation were excluded in order to avoid including cases of NI as a result of a previous hospital stay. If a patient had more than one stay for the selected CT or OP operation during the year, the first stay was designated the start date of follow-up. Patients were followed for $1 \mathrm{y}$, and all hospital stays were evaluated. An SI event was defined as one of the ICD-10 codes corresponding to SI (A410, A411, A412, A490, B956, B957, B958; Appendix 2) during a stay within $90 \mathrm{~d}$ after the first operation. Patients being admitted before the $90 \mathrm{~d}$ cut-off but being discharged after $90 \mathrm{~d}$ were still taken into account for the entirety of their stay. A sub-group analysis was conducted on in-hospital- and post-discharge-infected patients (Fig. 1).

\section{Study variables}

Demographic variables included gender and age. Age was considered as a continuous variable and also categorized into four groups ( $<61 \mathrm{y}, 61-70 \mathrm{y}, 71-80 \mathrm{y},>80 \mathrm{y}$ ). Epidemiologic and clinical outcomes included the type of operation (selected CT/OP), occurrence of SI (infected/non-infected), death, number of hospitalizations during follow-up, reasons for hospitalization (first surgery, other surgery related to pathology or infection, or other), and hospital LOS. An additional variable was used to indicate the timing of infection: Either during (in-hospital) or after (post-discharge) the surgical stay. The economic variable was the cost of each stay.

\section{Economic evaluation}

The hospital perspective was considered for the analysis. Cost was obtained using the 2009 national cost study (ENC), which is a permanent study conducted among hospitals to define a cost for each DRG based on the real cost for hospitals, not only hospital charges. The ENC sample for private hospitals was not representative in 2009; therefore, cost for public hospitals was used as a proxy for private hospitals [11].

\section{Statistical analysis}

Statistical analysis was performed using SAS version 9.2 (SAS Institute, Cary, NC). Numbers and percents were provided for categorical variables. Mean value, standard deviation (SD), median, outliers, and quartiles were reported for continuous variables. The number of missing values was specified. Results for categorical variables were compared

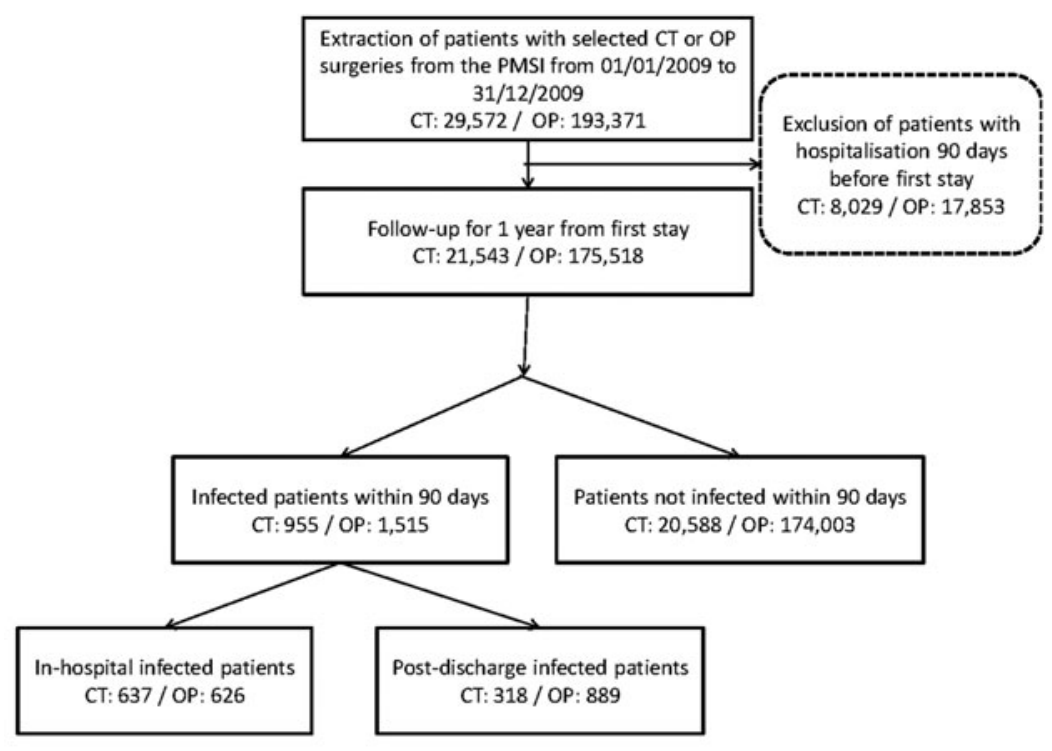

Note: CT: selected cardiothoracic surgeries; OP: selected orthopedic surgeries; PMSI: French hospital discharge database

FIG. 1. Process for selection of patients. 
Table 1. Characteristics of Patients in Defined CT AND OP SURGERY Groups

\begin{tabular}{|c|c|c|}
\hline & $\begin{array}{l}\text { Selected } C T \\
(\mathrm{n}=21,543)\end{array}$ & $\begin{array}{l}\text { Selected } O P \\
(\mathrm{n}=175,518)\end{array}$ \\
\hline \multicolumn{3}{|l|}{ Gender (\%) } \\
\hline Male & $15,596(72.4)$ & $66,864(38.1)$ \\
\hline Female & $5,947(27.6)$ & $108,654(61.9)$ \\
\hline \multicolumn{3}{|l|}{ Age (years) } \\
\hline $\begin{array}{l}\text { Missing } \\
\text { information }\end{array}$ & 12 & 0 \\
\hline Mean (SD) & $67.9(11.9)$ & $71.7(11.5)$ \\
\hline $\begin{array}{l}\text { Median } \\
\quad(\min -\max )\end{array}$ & $70.0(1.0-100.0)$ & $73.0(1.0-107.0)$ \\
\hline Q1-Q3 & $61.0-77.0$ & $64.0-80.0$ \\
\hline \multicolumn{3}{|l|}{ Age group (\%) } \\
\hline $\begin{array}{l}\text { Missing } \\
\text { information }\end{array}$ & 12 & 0 \\
\hline$<61$ y & $5,327(24.7)$ & $29,492(16.8)$ \\
\hline $61-70 y$ & $5,796(26.9)$ & $42,733(24.3)$ \\
\hline $71-80 y$ & 7,790 (36.2) & $63,415(36.1)$ \\
\hline$>80 y$ & $2,618(12.2)$ & $39,878(22.7)$ \\
\hline \multicolumn{3}{|l|}{$\mathrm{CT}$ procedure $(\%)$} \\
\hline $\begin{array}{l}\text { Missing } \\
\text { information }\end{array}$ & 0 & \\
\hline $\begin{array}{c}\text { Coronary artery } \\
\text { bypass graft }\end{array}$ & $13,421(62.3)$ & - \\
\hline $\begin{array}{l}\text { Heart valve } \\
\text { replacement }\end{array}$ & $8,122(37.7)$ & - \\
\hline \multicolumn{3}{|l|}{ OP procedure $(\%)$} \\
\hline Knee arthroplasty & - & $63,144(36.0)$ \\
\hline Hip arthroplasty & - & $112,374(64.0)$ \\
\hline
\end{tabular}

$\mathrm{CT}=$ cardiothoracic $; \mathrm{OP}=$ orthopedic $; \mathrm{SD}=$ standard deviation .

using the Fisher exact test, whereas the results for continuous variables were compared using the Wilcoxon rank-sum test. Adjustments of gender, age, and procedure were made for cost comparisons using the Kruskall-Wallis test. A p value $<0.05$ was considered statistically significant.

\section{Results}

\section{Patient characteristics}

A total of 21,543 and 175,518 patients underwent at least one of the selected CT or OP operations, respectively, in 2009

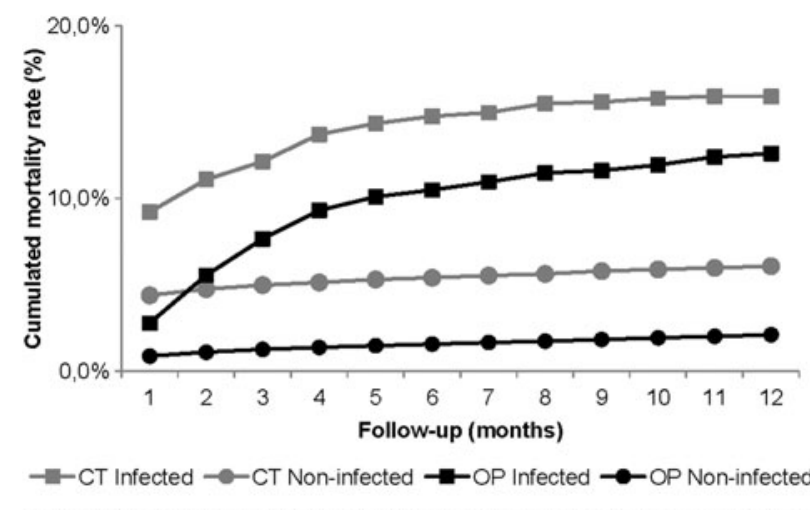

Note: CT: selected cardiothoracic surgeries; OP: selected orthopedic surgeries

FIG. 2. Cumulative mortality rate over 12 months of study.
(Table 1). In the CT group, most $(72.4 \%)$ of patients were male, and the mean age was $67.9 \pm 11.9 \mathrm{y}$. Approximately two-thirds of the patients had a CABG, and one-third had heart valve replacement. In the OP group, $38.1 \%$ of patients were male, and the mean age was $71.7 \pm 11.5 \mathrm{y}$. About twothirds of the patients had hip arthroplasty, the remainder having knee arthroplasty.

\section{Epidemiologic Outcomes}

A total of 955 patients (4.4\%) who underwent the defined CT operations and 1,515 patients $(0.9 \%)$ who underwent the defined OP operations developed SI within $90 \mathrm{~d}$ after surgery, among whom 637 (67\%) and $626(41.3 \%)$, respectively, developed the infection in-hospital. Among patients having CT surgery, infected and non-infected groups were similar in terms of demographics. Of the 1,515 patients who developed SI after OP surgery, $46.1 \%$ were male compared with $38.0 \%$ of the non-infected group $(\mathrm{p}<0.0001)$. Infected patients were slightly older (mean age 74.7 vs. $71.7 \mathrm{y} ; \mathrm{p}<$ $0.0001)$. Overall, the in-hospital mortality rate for infected patients was twice as high in the CT surgery group (15.9\% vs. $6.1 \% ; \mathrm{p}<0.0001)$ and six-fold greater in the OP surgery group $(12.6 \%$ vs. $2.1 \% ; \mathrm{p}<0.0001)$ than in non-infected patients. The in-hospital mortality rate was substantially greater during the first 5 mos of follow-up (Fig. 2).

\section{Clinical outcomes}

In the CT surgery group, the proportion of patients rehospitalized for additional surgery related to pathology or infection was significantly greater in infected patients than in non-infected patients $(21.3 \%$ vs. $7.1 \%)$. Similar results were found in the OP surgery group (33.1\% vs. $4.1 \%$ ) (Table 2).

For both the CT and the OP surgery groups, the mean number of hospitalizations over $1 \mathrm{y}$ was significantly greater in the infected than in the non-infected group. Infection led to approximately 1.0 and 1.4 additional hospitalizations per patient in the $\mathrm{CT}$ and OP groups, respectively (both $\mathrm{p}<0.0001$ vs. noninfected). The first stay was significantly longer for infected patients than non-infected patients in the CT and OP surgery groups $(\mathrm{CT}+9.5 \mathrm{~d}$; OP $+5.7 \mathrm{~d})$. Overall, the LOS of an infected patient was two-fold and 2.8-fold longer than that of a noninfected patient in the CT and OP groups, respectively. Infected patients spent 22.1 and 24.1 additional days in the hospital, respectively (both $\mathrm{p}<0.0001$ vs. non-infected).

\section{Economic outcomes}

The mean cost of an infected patient was $€ 38,228$ and $€ 24,170$ in the CT and OP surgery groups, respectively, compared with $€ 22,753$ and $€ 10,780$ in the non-infected groups. Infection thus leads to a significantly higher mean excess cost per patient ( $€ 15,475$ and $€ 13,389$ in the CT and OP groups, respectively) (Table 2). The first operation accounted for the greatest part of this cost for both infected and non-infected patients. The cost of subsequent hospitalizations for additional surgery related to pathology or infection was significantly higher in infected than in non-infected patients (CT €4,970 vs. €910; OP €5,076 vs. €323). Overall, the total hospital cost of these kinds of CT and OP operations in France in 2009 reached $€ 505$ million and $€ 1.9$ billion, respectively, over a 1-y follow-up period. The management of SI in CABG or valve replacement (CT) and knee or hip 


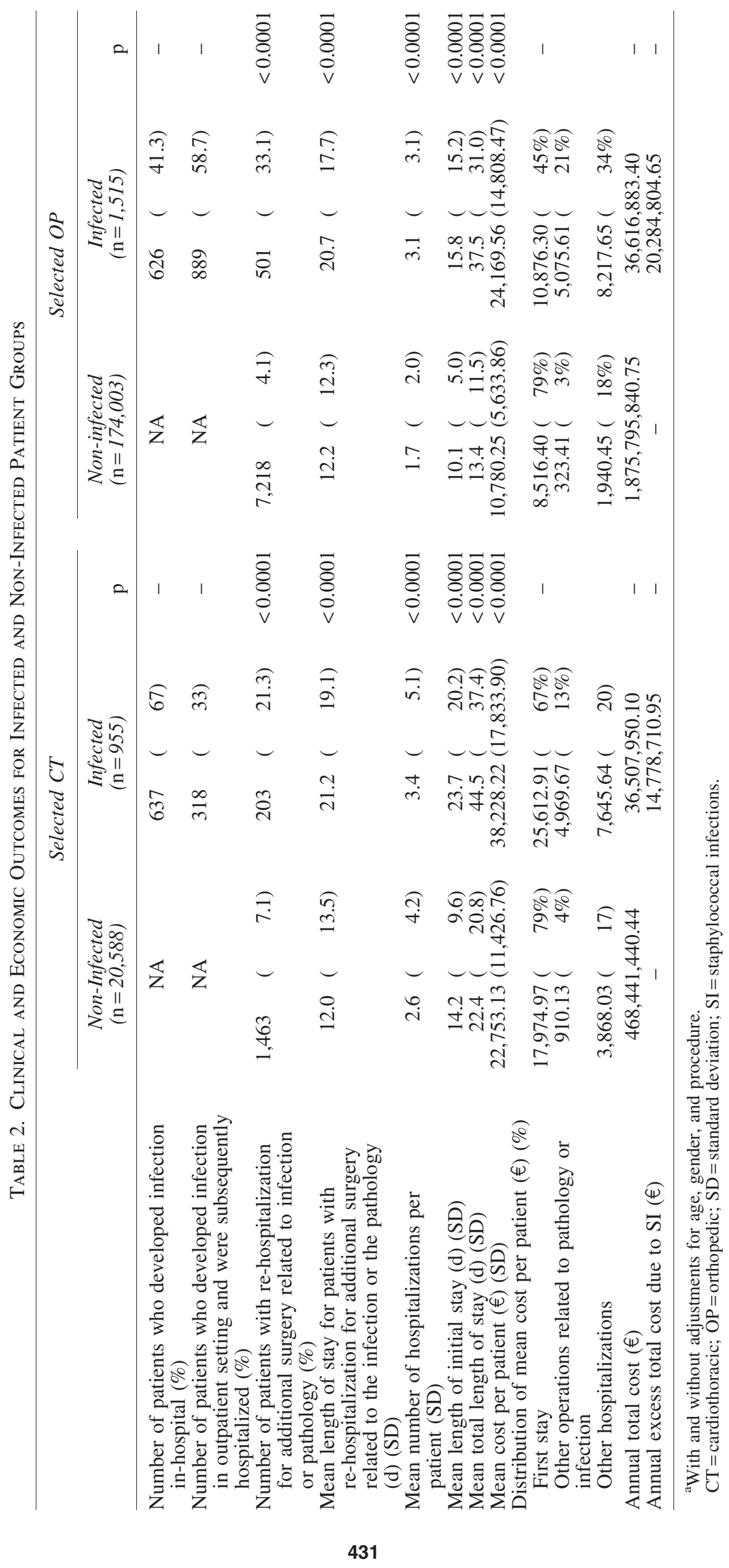


arthroplasty (OP) operations accounted for $€ 15$ million and $€ 20$ million of these costs, respectively.

\section{Subgroup analyses: In-hospital and post-discharge infections}

Selected CT procedures. Of the infected patients from the CT surgery group $(\mathrm{N}=955), 637(66.7 \%)$ developed SI during their hospital stays, whereas 318 (33.3\%) developed infection after discharge from the hospital. Demographic variables were similar in these groups of patients. No statistical difference was observed in the in-hospital mortality rate.

The mean number of hospitalizations was significantly greater in the post-discharge-infected group than in the inhospital-infected group $(4.9 \pm 5.9$ vs. $2.7 \pm 4.5 ; \mathrm{p}<0.0001)$. Not surprisingly, the initial surgical stay was significantly shorter for patients who developed SI after discharge than for those who developed the infection in the hospital (15.6 \pm $11.5 \mathrm{~d}$ vs. $27.8 \pm 22.3 \mathrm{~d} ; \mathrm{p}<0.0001)$. However, the overall mean LOS was significantly longer in the post-dischargeinfected group $(55.1 \pm 37.9$ d vs. $39.3 \pm 36.0 \mathrm{~d}$; $\mathrm{p}<0.0001)$. The mean cost per patient was significantly higher for patients in the post-discharge-infected group than in the inhospital-infected group (€44,345 $\pm 20,513$ vs. $€ 35,174 \pm$ $15,468 ; \mathrm{p}<0.0001)$.

Selected OP procedures. Of the infected patients in the OP surgery group $(\mathrm{N}=1,515), 626(41.3 \%)$ developed SI during their hospital stay, whereas 889 (58.7\%) developed infection after hospital discharge. Demographic variables, with the exception of gender, were similar in the two groups; there were significantly more males among the patients infected post-discharge group (48.5\% vs. $42.7 \%$; $\mathrm{p}=0.0279)$. The mean number of hospitalizations for infected patients was significantly greater in the post-discharge group than in the in-hospital group $(3.8 \pm 3.4$ vs. $2.0 \pm 2.1 ; \mathrm{p}<0.0001)$. The initial surgical stay was significantly shorter for patients who developed SI after discharge than for those who developed an infection in hospital (12.6 $\pm 8.7 \mathrm{~d}$ vs. $20.3 \pm 20.3 \mathrm{~d}$; $\mathrm{p}<0.0001)$. The overall mean LOS for infected patients was $50 \%$ longer in the post-discharge group than in the in-hospital group $(43.7 \pm 30.2 \mathrm{~d}$ vs. $28.8 \pm 30.0 \mathrm{~d} ; \mathrm{p}<0.0001)$. The mean cost per patient who developed SI was significantly higher in the post-discharge group than in the in-hospital group $(€ 29,143 \pm 15,385$ vs. $€ 17,107 \pm 10,476 ; p<0.0001)$.

\section{Discussion}

This analysis of the PMSI database shows that post-operative SI have an important clinical and economic impact in France. In $2009,4.4 \%$ and $0.9 \%$ of patients, respectively, who underwent the most common $\mathrm{CT}$ and OP surgery procedures developed SI. These results are consistent with published literature on the incidence of SI. A report from the French Senate in 2006 stated that $5 \%$ to $6 \%$ of patients hospitalized in France develop NI [12]. Specifically, NI occur in surgical wards, as reported in an annual survey conducted on surgical site infections by the French National Institute for Sanitary Surveillance (InVS) in 2003. Of 107,576 surgical interventions, 2,169 $(0.7 \%)$ were followed by surgical site infections (SSIs), $44.3 \%$ of which occurred after discharge [12]. The Helics study in 2000-2003, in which 171,927 surgical interventions in 600 hospitals in 10 European countries were evaluated, reported a cumulative SSI incidence in France of $4.0 \%$ after bypass surgery and $1.3 \%$ after hip surgery. Staphylococcus aureus was one of the most common pathogens $(43.7 \%$ and $48.6 \%$ for bypass and hip operations, respectively) [12]. A Swiss study published in 2012 based on the Basel cohort database reported an overall SSI rate of $4.7 \%$, with $S$. aureus again the most common pathogen (29\%)[6].

Our study provides information pertaining to previously unexamined outcomes in France and fits into the context of ever-increasing French measures to limit NI. In 2001, the aforementioned national surveillance and alert network was put into place. Other recent measures include increasing the requirements regarding composite NI scores to the yearly NI performance indicator scorecard, as well as publishing the results of individual hospitals for public information. The results of these measures were demonstrated in the report on the national NI and antimicrobial treatment point-prevalence survey for 2012 [3]. Compared with the results from 2006, the prevalence of methicillin-resistant $S$. aureus (MRSA) NI decreased by $50 \%$, whereas the number of methicillin-sensitive $S$. aureus (MSSA) NI remained stable. With regard to SSIs, there was a $7.2 \%$ decrease in prevalence, with an $11.6 \%$ reduction in the prevalence of S. aureus infections. Staphylococcus aureus remained the bacterium most commonly isolated in SSIs in 2012, at $29.2 \%$ of isolated bacteria. These data, which pertain to prevalence, are not directly comparable to our results but suggest that there were moderate decreases in the prevalence of NI, SI, and SSI between 2006 and 2012.

Our study confirms that over a one-year follow-up period, patients with SI after the most common CT or OP operations had a significantly greater re-hospitalization rate, a larger number of hospitalizations, a longer LOS during the first stay and during all hospitalizations, and a greater in-hospital mortality rate. No other study evaluating these outcomes has been published in France. The Swiss Basel case-control study showed that the mean post-operative LOS for patients with SSIs was twice that for patients without infection (29.0 vs. $12.3 \mathrm{~d} ; \mathrm{p}=0.001)$, resulting in a mean additional postoperative hospital stay of 16.8 d (95\% CI 13-20.6 d)[6]. Similarly, in our study, the LOS was $50 \%$ longer for infected patients than for non-infected patients after the selected CT or OP surgery (CT 23.7 vs. $14.2 \mathrm{~d}$ and OP 15.2 vs. $10.1 \mathrm{~d}$ ).

Consistent with published literature, our study also showed that SI is associated with an excess cost per patient of $€ 15,475$ and $€ 13,389$, respectively, for patients having received the two most common types of CT and OP operations. A previous review of studies evaluating the economic impact of NI in France indicated that excess cost per patient ranged from $€ 1,500$ to $€ 27,340$, depending on the pathogen, infection type, and underlying disease [2].

Our study has some limitations. First, clinical and economic outcomes were collected during hospital stays only; events occurring between hospitalizations were not included in either the PMSI database or our study. This implies that our study reflects the real cost and clinical impact of SI to hospitals after the selected CT or OP operations in France but does not account for the cost associated with ambulatory care, the overall burden to the national health insurance, or the cost burden to patients. In addition, only the in-hospital mortality rates were estimated. Therefore, the real impact of SI on the mortality rate may be underestimated. However, the potential bias is assumed to be the same among infected and non-infected patients. 
Additionally, this study was descriptive and cannot demonstrate causality between SI infection and increased cost and burden because of the presence of co-morbidities, although it can describe the higher cost and burden in the infected population vs. the non-infected one. Furthermore, although the primary objective of the study was not comparative, casematching based on age, gender, and types of surgical procedures produced results showing comparable significant differences between groups (Table 2). Finally, there is no consensus on the appropriate delay to be considered between the infection and the appearance of symptoms; in this study, we chose 90 days.

Our findings revealed significant impacts of SI after CABG or valve replacement and knee or hip arthroplasty surgery on LOS, re-hospitalization rate, number of hospitalizations, and cost. In addition, infection developing after hospital discharge has a significantly greater impact on clinical and economic outcomes than in-hospital infection. Further measures will be needed to reduce the clinical and economic impact of SI on surgical wards.

\section{Acknowledgments}

We thank Wouter Houthoofd (XPE Pharma and Science) for publication coordination on behalf of GSK Vaccines. We also thank Joelle Wauquaire and Raymond de Burlet from the GSK Vaccines Information Center for support in the literature search.

Financial support for this research and development of this manuscript was provided by GlaxoSmithKline Biologicals SA, Rixensart, Brabant Wallon, Belgium.

\section{Author Disclosure Statement}

Aurélie Schmidt and Stève Bénard are employees of st[è]ve consultants, which received funding from the GSK group of companies to conduct the research and provide writing assistance. Sonya Cyr is employed by GSK and owns GSK stock options. The authors have no other conflicts to declare.

\section{References}

1. Kelly KN, Monson JRT. Hospital-acquired infections. Surgery 2012;30:640-644.
2. Durand-Zaleski I, Chaix C, Brun Buisson C. Le coût des infections liées aux soins. Act Doss Santé Publique 2002; 38:29-31.

3. Réseau d'Alerte d'Investigation et de Surveillance des Infections Nosocomiales. Enquête nationale de prévalence des infections nosocomiales et des traitements antiinfectieux en établissements de santé, France, mai-juin 2012. Saint-Maurice. Institut de Veille Sanitaire 2013:181.

4. Bossard N. Using data from the French hospital database (PMSI) to estimate district-specific cancer incidence: The ONCEPI group approach. BEH 2012;5-6.

5. Goyal N, Miller A, Tripathi M, Parvizi J. Methicillinresistant Staphylococcus aureus: Colonisation and preoperative screening. J Bone Joint Surg 2013;95(B):4-9.

6. Junker T, Mujagic E, Hoffmann H, et al. Prevention and control of surgical site infections: Review of the Basel Cohort Study. Swiss Med Wkly 2012;142:w13616.

7. Van Rijen MM, Bode LG, Baak DA, et al. Reduced costs for Staphylococcus aureus carriers treated prophylactically with mupirocin and chlorhexidine in cardiothoracic and orthopaedic surgery. PLoS One 2012;7:e43065.

8. Chen AF, Wessel CB, Rao N. Staphylococcus aureus screening and decolonization in orthopaedic surgery and reduction of surgical site infections. Clin Orthop Relat Res 2013;(471):2383-2399.

9. Kalra L, Miller M, Du P, et al. Risk of methicillin-resistant Staphylococcus aureus (MRSA) surgical site infection in patients with nasal MRSA colonization undergoing orthopedic/spine surgery. Am J Infect Control 2011;39:E61.

10. Kashimura N, Kusachi S, Konishi T, et al. Impact of surgical site infection after colorectal surgery on hospital stay and medical expenditure in Japan. Surg Today 2012;42: 639-645.

11. Agence Technique de l'Information sur l'Hospitalisation. Référentiel de coûts MCO 2009. Agence Technique 2011.

12. Senat-Office parlementaire d'évaluation des politiques de santé. La politique de lutte contre les infections nosocomiales. Paris. 2006.

Address correspondence to: Dr. Aurélie Schmidt St[è]ve Consultants 30 rue Narcisse Bertholey 69600 Oullins, France

E-mail: aschmidt@steve-consultants.com

Appendix 1. Selected CT and OP Procedures (in the Original French)

\section{Coronary artery bypass graft}

DDMA025 Revascularisation coronaire par un greffon artériel avec une anastomose distale, par thoracotomie sans CEC DDMA015 Revascularisation coronaire par un greffon artériel avec une anastomose distale, par thoracotomie avec CEC DDMA023 Revascularisation coronaire par un greffon artériel avec 2 anastomoses distales, par thoracotomie sans CEC DDMA017 Revascularisation coronaire par un greffon artériel avec 2 anastomoses distales, par thoracotomie avec CEC

DDMA032 Revascularisation coronaire par un greffon artériel et par greffon veineux avec 2 anastomoses distales, par thoracotomie sans CEC

DDMA011 Revascularisation coronaire par un greffon artériel et par greffon veineux avec 2 anastomoses distales, par thoracotomie avec CEC

DDMA029 Revascularisation coronaire par un greffon artériel et par greffon veineux avec 3 anastomoses distales, par thoracotomie sans CEC

DDMA018 Revascularisation coronaire par un greffon artériel et par greffon veineux avec 3 anastomoses distales, par thoracotomie avec CEC 
Appendix Table A1. (Continued)

DDMA038 Revascularisation coronaire par un greffon artériel et par greffon veineux avec 4 anastomoses distales ou plus, par thoracotomie sans CEC

DDMA021 Revascularisation coronaire par un greffon artériel et par greffon veineux avec 4 anastomoses distales ou plus, par thoracotomie avec CEC

DDMA026 Revascularisation coronaire par 2 greffons artériels avec 2 anastomoses distales, par thoracotomie sans CEC DDMA020 Revascularisation coronaire par 2 greffons artériels avec 2 anastomoses distales, par thoracotomie avec CEC DDMA031 Revascularisation coronaire par 2 greffons artériels avec 3 anastomoses distales, par thoracotomie sans CEC DDMA006 Revascularisation coronaire par 2 greffons artériels avec 3 anastomoses distales, par thoracotomie avec CEC

DDMA033 Revascularisation coronaire par 2 greffons artériels avec 4 anastomoses distales ou plus, par thoracotomie sans CEC

DDMA008 Revascularisation coronaire par 2 greffons artériels avec 4 anastomoses distales ou plus, par thoracotomie avec CEC

DDMA022 Revascularisation coronaire par 2 greffons artériels et par greffon veineux avec 3 anastomoses distales, par thoracotomie sans CEC

DDMA005 Revascularisation coronaire par 2 greffons artériels et par greffon veineux avec 3 anastomoses distales, par thoracotomie avec CEC

DDMA034 Revascularisation coronaire par 2 greffons artériels et par greffon veineux avec 4 anastomoses distales ou plus, par thoracotomie sans CEC

DDMA009 Revascularisation coronaire par 2 greffons artériels et par greffon veineux avec 4 anastomoses distales ou plus, par thoracotomie avec CEC

DDMA030

Revascularisation coronaire par 3 greffons artériels avec 3 anastomoses distales, par thoracotomie sans CEC

DDMA003

Revascularisation coronaire par 3 greffons artériels avec 3 anastomoses distales, par thoracotomie avec CEC

Revascularisation coronaire par 3 greffons artériels avec 4 anastomoses distales ou plus, par thoracotomie sans CEC

DDMA013 Revascularisation coronaire par 3 greffons artériels avec 4 anastomoses distales ou plus, par thoracotomie avec CEC

DDMA036 Revascularisation coronaire par 3 greffons artériels et par greffon veineux avec 4 anastomoses distales ou plus, par thoracotomie sans CEC

DDMA012 Revascularisation coronaire par 3 greffons artériels et par greffon veineux avec 4 anastomoses distales ou plus, par thoracotomie avec CEC

DDMA028

DDMA007

DDMA024

DDMA019

DDMA027

DDMA016

DDMA037

Revascularisation coronaire par greffon veineux avec une anastomose distale, par thoracotomie sans CEC

Revascularisation coronaire par greffon veineux avec une anastomose distale, par thoracotomie avec CEC

Revascularisation coronaire par greffon veineux avec 2 anastomoses distales, par thoracotomie sans CEC

Revascularisation coronaire par greffon veineux avec 2 anastomoses distales, par thoracotomie avec CEC

Revascularisation coronaire par greffon veineux avec 3 anastomoses distales, par thoracotomie sans CEC

Revascularisation coronaire par greffon veineux avec 3 anastomoses distales, par thoracotomie avec CEC

Revascularisation coronaire par greffon veineux avec 4 anastomoses distales ou plus, par thoracotomie sans CEC

DDMA004 Revascularisation coronaire par greffon veineux avec 4 anastomoses distales ou plus, par thoracotomie avec CEC

Heart valve replacement

DBKA004 Remplacement de la valve atrioventriculaire droite par prothèse mécanique ou bioprothèse avec armature, par thoracotomie avec CEC

DBKA008 Remplacement de la valve atrioventriculaire droite par homogreffe, par thoracotomie avec CEC

DBKA007 Remplacement de la valve pulmonaire par prothèse mécanique ou bioprothèse avec armature, par thoracotomie avec CEC

DBKA012 Remplacement de la valve pulmonaire par homogreffe ou bioprothèse sans armature, par thoracotomie avec CEC

DBKA010 Remplacement de la valve atrioventriculaire gauche par prothèse mécanique ou bioprothèse avec armature, par thoracotomie avec CEC

DBKA005 Remplacement de la valve atrioventriculaire gauche par homogreffe, par thoracotomie avec CEC

DBKA002 Remplacement de la valve atrioventriculaire gauche par prothèse en position non anatomique, par thoracotomie avec CEC

DBKA006 Remplacement de la valve aortique par prothèse mécanique ou bioprothèse avec armature, par thoracotomie avec CEC

DBKA003 Remplacement de la valve aortique par bioprothèse sans armature, par thoracotomie avec CEC

DBKA001 Remplacement de la valve aortique par homogreffe, par thoracotomie avec CEC

DBKA011 Remplacement de la valve aortique par prothèse en position non anatomique, par thoracotomie avec CEC

DBKA009 Remplacement de la valve aortique et de la valve atrioventriculaire gauche par prothèse mécanique ou par bioprothèse avec armature, par thoracotomie avec CEC

Coxofemoral arthroplasty

NEMA020 Acétabuloplastie avec ostéotomie du fémur

NEMA018 Arthroplastie coxofémorale par cupule fémorale

NEKA018 Remplacement de l'articulation coxofémorale par prothèse fémorale cervicocéphalique 
Appendix Table A1. (Continued)

NEKA011 Remplacement de l'articulation coxofémorale par prothèse fémorale cervicocéphalique et cupule mobile

NELA003 Pose d'une pièce acétabulaire chez un patient porteur d'une prothèse fémorale cervicocéphalique homolatérale

Totalisation d'une prothèse unipolaire de hanche

NEKA020 Remplacement de l'articulation coxofémorale par prothèse totale Pose de prothèse totale de hanche

NEKA012 Remplacement de l'articulation coxofémorale par prothèse totale, avec reconstruction acétabulaire ou fémorale par greffe

NEKA014 Remplacement de l'articulation coxofémorale par prothèse totale, avec renfort métallique acétabulaire À l'exclusion de : avec utilisation de vis pilotis

NEKA010 Remplacement de l'articulation coxofémorale par prothèse totale, avec renfort métallique acétabulaire et reconstruction fémorale par greffe

NEKA016 Remplacement de l'articulation coxofémorale par prothèse totale, avec ostéotomie de la diaphyse du fémur

NEKA017 Remplacement de l'articulation coxofémorale par prothèse totale, avec abaissement de la tête du fémur dans le paléoacétabulum [paléocotyle]

Pose de prothèse totale pour luxation congénitale haute ou intermédiaire de la hanche

Avec ou sans : reconstruction acétabulaire par greffe ou renfort prothétique

NEKA021 Remplacement de l'articulation coxofémorale par prothèse totale, avec abaissement de la tête du fémur dans le paléoacétabulum [paléocotyle] et ostéotomie de réaxation ou d'alignement du fémur

Pose de prothèse totale pour luxation congénitale haute ou intermédiaire de la hanche avec ostéotomie du fémur

Avec ou sans : reconstruction acétabulaire par greffe ou renfort prothétique

NEKA015 Remplacement de l'articulation coxofémorale par prothèse totale après ostéosynthèse, ostéotomie ou prothèse cervicocéphalique du fémur

Avec ou sans : ablation de matériel prothétique

NEKA013 Remplacement de l'articulation coxofémorale par prothèse totale après arthrodèse coxofémorale

NEKA019 Remplacement de l'articulation coxofémorale par prothèse totale après arthrodèse coxofémorale, avec renfort métallique acétabulaire

À l'exclusion de : avec utilisation de vis pilotis

Knee arthroplasty

NFKA009 Remplacement de l'articulation du genou par prothèse à charnière fixe ou rotatoire

NFKA006 Remplacement de l'articulation du genou par prothèse unicompartimentaire fémorotibiale ou fémoropatellaire

NFKA007 Remplacement de l'articulation du genou par prothèse tricompartimentaire sur une déformation inférieure ou égale à $10^{\circ}$ dans le plan frontal

NFKA008 Remplacement de l'articulation du genou par prothèse tricompartimentaire sur une déformation supérieure à $10^{\circ}$ dans le plan frontal

Appendix 2. Staphylococcal Infection Diagnoses

Staphylococcus aureus

A410

B956

Other Staphylococcus

A411

A412

A490

B957

B958
Septicemia secondary to Staphylococcus aureus

Staphylococcus aureus as the cause of disease classified to other chapters

Septicemia secondary to other specified Staphylococcus

Septicemia secondary to unspecified Staphylococcus

Staphylococcal infection unspecified

Other Staphylococcus as the cause of diseases classified to other chapters

Unspecified Staphylococcus as the cause of diseases classified to other chapters 